\title{
Evidence of clonal budding in a radial cluster of Paraconularia crustula (White) (Pennsylvanian: ?Cnidaria)
}

\author{
HEYO VAN ITEN AND ROBT S. COX
}

LETHAIA

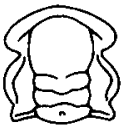

\begin{abstract}
Van Iten, H. \& Cox, R. S. 199210 15: Evidence of clonal budding in a radial cluster of Paraconularia crustula (White) (Pennsylvanian: ?Cnidaria). Lethaia, Vol. 25, pp. 421-426. Oslo. ISSN 0024-1164.

Monospecific conulariid clusters have been interpreted as products of gregarious behavior or as clonal colonies, with members of a colony originally inclined at a high angle to the substrate and connected to each other at their apices. However, individuals in all previously documented clusters are preserved parallel, or nearly parallel, to bedding, and their apices are not preserved. We describe a cluster of three Paraconularia crustula (White) (Pennsylvanian of Missouri, USA) in which the individual specimens exhibit an original steeply inclined orientation. The individuals in this cluster converge adapically on an extremely thin, crumpled sheet of apatitic material that is similar to conulariid test material. The conulariids and associated sheet bear a striking resemblance to regenerated, clonal colonies of polypoid coronatid scyphozoans. Such colonies arise from a thin, periderm-covered sheet of non-differentiated soft tissue, produced following severance of a single parent polyp. We suggest that the conulariid cluster originated through a similar process. Should this interpretation be corroborated by the discovery of better preserved conulariid clusters, it would provide strong additional evidence for the hypothesis of a scyphozoan affinity for conulariids. $\square$ Conulariids, PARACONULARIs, scyphozoans, clonal budding. conulariid paleobiology, conularid affinities, Pennsylvanian.
\end{abstract}

Heyo Van Iten and Robt S. Cox, Museum of Paleontology, University of Michigan, Ann Arbor, Michigan, 48109, USA; receined 18th October, 1991, revised typescript accepted 26th April, 1992.

Despite continuing dispute over the problem of conulariid affinities, a consensus is emerging among paleontologists that conulariids were sessile organisms, attached by their apex to shells or other hard materials and inclined at a high angle to their substrate (e.g. Finks 1955, 1960; Harland \& Pickerill 1987; Babcock et al. 1987; Babcock 1991; Van Iten 1991a-c). Less well agreed upon, however, is the nature of monospecific conulariid clusters. Of particular interest are clusters in which some or all individuals converge adapically on a common center (Fig. 1; see also Ruedemann 1925: pl. 22, fig. 3; Sinclair 1940: pl. 2, fig. 5; Babcock \& Feldmann 1986a: fig. 4; Babcock \& Feldmann 1986b: fig. 24; Van Iten 1991c: textfig. 4a). We here refer to such clusters as radial clusters. Previously documented radial clusters (Table 1) contain anywhere from two to twenty or more individuals. Probably as a result of postmortem compaction, conulariids in most of these clusters are flattened and oriented parallel, or nearly parallel, to bedding.

To date, two alternative hypotheses of the nature of conulariid clusters have been offered. One of these, most recently advocated by Babcock (1991), is that clusters are products of 'gregarious' behavior. Since conulariids were sessile animals, this would mean that clustering was caused by settling of two or more conulariid larvae next to each other. The second hypothesis is that clusters represent clonally budded colonies, with members of a colony attached to each other at their apices (Termier \& Termier 1949, 1953; Bischoff 1978; Van Iten 1987, 1991c).

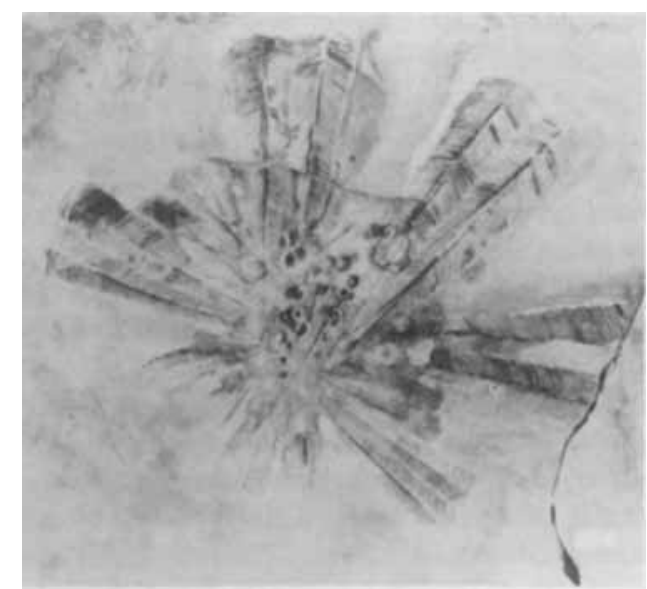

Fig. 1. Radial cluster of Paraconularia tenuis (Slater) (Lower Carboniferous, Cementstone Group, Scotland; BMNH G11798). Note the large number of individuals in the cluster and the poor preservation of their apical ends. Figure taken from Slater (1907, pl. 2, fig. 1). Scale bar $=1 \mathrm{~cm}$. 
Table 1. Listing of radial conulariid clusters examined in the present study, including clusters previously documented in the literature. $N=$ number of specimens comprising a cluster. All clusters listed are preserved in shale or lime mudstone. Repository abbreviations are as follows: BMNH = British Museum (Natural History), London; BMS $=$ Buffalo Museum of Science, Buffalo, New York: CMNH = Cleveland Museum of Natural History, Cleveland, Ohio; NYSM = New York State Museum, Albany, New York; SUI = State University of Iowa, Iowa City; USNM = United States National Museum, Washington.

\begin{tabular}{|c|c|c|c|c|}
\hline Repository & Host Unit & Taxon & $\mathbf{N}$ & Reference \\
\hline SUI 49979 & $\begin{array}{l}\text { Maquoketa Fm., Elgin Mbr., Unit } 1 . \\
\text { (Ordovician, lowa) }\end{array}$ & Canularia splendida & 8 & Van Iten, in press \\
\hline NYSM 9417 & $\begin{array}{l}\text { Lockport Fm., Gaspont Lens (Silurian. } \\
\text { New York) }\end{array}$ & Conularia tenuicosta & 2 & Ruedemann 1925 \\
\hline BMS E12301 & $\begin{array}{l}\text { Lackport Fm., Gasport Lens (Silurian, } \\
\text { New York) }\end{array}$ & Metaconularia nuda & 4 & Sinclair 1940 \\
\hline SUI 37414 & Mosalem Shale Fm. (Silurian, Iowa) & Metaconularia sp. & 4 & Ūndocumented \\
\hline$\overline{\text { NYSM } 3483}$ & $\begin{array}{l}\text { Ithaca Shale Fm. (Devonian, New } \\
\text { York) }\end{array}$ & Conularia congregata & 13 & $\begin{array}{l}\text { Babcock \& Feldman } \\
1986 \mathrm{a}\end{array}$ \\
\hline CMNH 1788 & Chagrin Shaje Fm. (Devonian, Ohio) & Paraconularia chesterensis & $\overline{2}$ & $\begin{array}{l}\text { Babcock \& Feldman } \\
1986 \mathrm{~b}\end{array}$ \\
\hline USNM 50150 & $\begin{array}{l}\text { Borden Group (Mississippian, } \\
\text { Indiana) }\end{array}$ & Paraconularia chesterensis & $20+$ & $\begin{array}{l}\text { Babcock \& Feldman } \\
1986 \mathrm{~b}\end{array}$ \\
\hline BMNH GI1798 & $\begin{array}{l}\text { Cementstone Group (Lower } \\
\text { Carboniferous, Scotland) }\end{array}$ & Paraconularia tenuis & $17+$ & Slater 1907 \\
\hline BMNH 17664 & $\begin{array}{l}\text { Cementstone Group (Lower } \\
\text { Carboniferous, Scotland) }\end{array}$ & Paraconularia tenuis & 7 & Undocumented \\
\hline BMNH 17662 & $\begin{array}{l}\text { Cementstone Group (Lower } \\
\text { Carboniferous, Scotland) }\end{array}$ & Paraconularia tenuis & 4 & Undocumented \\
\hline USNM 50145 & $\begin{array}{l}\text { Unidentified shale (Pennsylvanian, } \\
\text { Missouri) }\end{array}$ & Paraconularia cnustula & 3 & This report \\
\hline USNM 50148 & $\begin{array}{l}\text { Unidentified shale (Pennsylvanian, } \\
\text { Missouri) }\end{array}$ & Paraconularia crustula & 3 & Undocumented \\
\hline \multicolumn{3}{|c|}{ Total } & $87+$ & \\
\hline
\end{tabular}

Evidence thought to bear on this problem has been the subject of some controversy. Kozłowski (1968), reporting on isolated conulariid apices bearing numerous, rootlet-like projections, documented one apex (Kozłowski 1968: fig. 20) exhibiting a structure which he suggested may be an incipient conulariid clone. Babcock (1991:138), challenging this interpretation, maintained that the specimens figured by Kozłowski (1968) 'are certainly not conulariids', based upon purported differences between them and 'true' conulariids. Instead, Babcock (1991:135; Babcock \& Feldmann 1986a) offered an alternative interpretation of conulariid apical anatomy, namely that conulariids 'had a closed apex' associated with a 'flexible, perhaps chitinoid, stalk that partially sheathed the apical end'. He (1991:135) further proposed that conulariid clusters 'indicate that conulariids were gregarious organisms', and appeared to reject the hypothesis that they were capable of asexual reproduction. This conclusion was based on the absence of direct evidence of an apical connection between conulariids in previously documented radial clusters. However, upon examination of these same clusters (Table 1), we find that none of the specimens contained in them preserves the apex. Thus, the lack of direct evidence of connection between conulariid specimens neither falsifies the clonal budding hypothesis nor corroborates the alternative hypothesis of preferential larval settlement.

Comparison of Kozłowski's (1968) illustrations with fossils accepted by Babcock (1991) as conulariids indicates that Kozłowski's specimens exhibit a suite of characters uniquely shared with conulariids. Kozłowski's specimens are phosphatic, finely lamellar and steeply pyramidal, and they have four faces crossed by closely spaced transverse ridges that arch toward the apertural end. In some specimens the ridges bear a single row of small, closely spaced tubercles (e.g. Kozłowski 1968: fig. 18), and/or are offset at the four corners (e.g. Kozłowski 1968: fig. 19). Contrary to statements in Babcock (1991), the corners of at least some of Kozłowski's specimens (e.g. Kozłowski 1968: fig. 19) are sulcate. Anatomical features cited by Babcock (1991) as grounds for removing Kozłowski's specimens from Conulariida are either demonstrably variable within Conulariida or subject to postmortem alteration (e.g. convexity of the faces, geometry of the transverse cross-section, disposition of transverse ribs at the midlines), or vary in the degree to which they are expressed (e.g. cor- 
ner grooves). Moreover, the apical ends of other conulariid specimens thought by Babcock (Babcock \& Feldmann 1986b: figs. 21.1, 24.2, 32.5) to support his reconstruction of the conulariid apex (Babcock 1991: fig. 1b) appear to be broken well above the apex and are certainly very poorly preserved, and we suggest that the 'stalk' may represent either an artifact of preparation (i.e. toolmarks) or very poorly preserved plant material (Babcock \& Feldmann 1986b: figs. 24.1, 24.2). None of the figured or described specimens can be interpreted as providing conclusive evidence for the existence of 'stalks' in conulariids.

Kozłowski's specimens, on the other hand, possess several characters diagnostic of Conulariida, and, in particular, their anatomy agrees closely with more or less complete specimens that are preserved near the apex. Therefore, possible evidence of clonal budding in Kozłowski's specimens cannot simply be dismissed simply by dismissing these specimens from the Conulariida.

The present article documents a radial cluster consisting of three conulariid specimens that exhibit an original three-dimensional disposition, and are associated with a crumpled, apatitic sheet-like structure near their apical ends. The cluster, currently housed in collections of the United States National Museum, Washington (USNM 50145), was collected from shales of Pennsylvanian (?Desmoinesian) age (stratigraphic unit unknown) near Kansas City, Missouri, USA. As will be discussed below, comparison of this specimen with colonial scyphozoan cnidarians, interpreted by a number of investigators (e.g. Werner 1966, 1967; Bischoff 1978, 1989; Van Iten 1991b, 1992a, b) as being closely related to conulariids, suggests that the specimen preserves independent evidence in support of the hypothesis that conulariid clusters represent clonal colonies.

\section{Description of the cluster}

USNM 50145 consists of part of a grey phosphatic(?) concretion containing three Paraconularia crustula (White) (Fig. 2). The orientation of the concretion as it occurred in outcrop is unknown, but if the axis of the cluster was originally vertical, the three conulariids were inclined at about $60^{\circ}$ to horizontal. One of the conulariid specimens (number 3 in Fig. 2A) is about $2.5 \mathrm{~cm}$ long and is nearly complete; the other two (num-
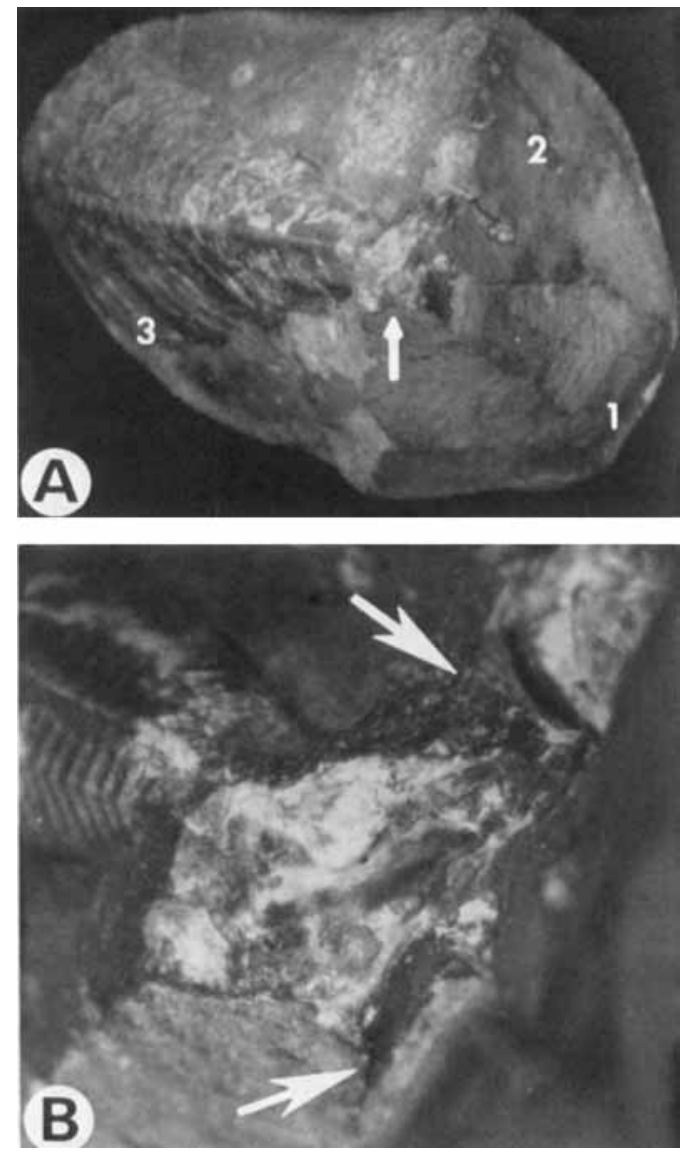

Fig. 2. Light photographs of conulariid cluster USNM 50145 , Paraconularia crustula (White). $\square$ A. View of the entire cluster (individuals numbered 1-3), looking down on the narrow end (arrow), $\times 2.5$. $\square$ B. Close-up of the same, showing the apatitic sheet and the apical end (arrows) of the two framentary conulariids, $\times 8.3$.

bers 1 and 2 in Fig. 2A) are fragmentary and each consist of part of a single face. The missing parts probably occurred in portions of the concretion that were not collected or are no longer available.

All three individuals converge adapically on an extremely thin (about $0.01 \mathrm{~mm}$ ), crumpled sheet of mineralized material that is similar in color and surface texture to the apatitic conulariid tests. The sheet is irregular in outline, with a maximum width of about $6 \mathrm{~mm}$, though most of its present margin is an artifact of breakage. Under magnification, the test material at the apical end of the two fragmentary conulariids (Fig. 2B, arrows) appears to be continuous with 
the sheet: however, the poor preservation of these areas makes it difficult to test this hypothesis conclusively. The apical ends of these two specimens appear to have terminated at a test width of about $1.5 \mathrm{~mm}$, well above the point at which their corners met (if they did meet). The apex of the nearly complete individual is either not preserved or is covered by rock matrix, and could not be examined.

\section{Discussion}

Comparison of USNM 50145 with conulariids overgrown in situ by sponges (Finks 1955, 1960; Van Iten 1991a) suggests that the spatial disposition of the conulariids is primary, and that they originally rested on their apices. Clusters of erect, non-encrusted conulariids (Paraconularia) have also been reported, though not documented, from a black shale horizon in the Colony Creek Shale (Pennsylvanian, north-central Texas, USA; Rooke \& Carew 1983). These clusters, which were examined in outcrop but not collected, consisted of one relatively large individual surrounded by several smaller ones (J. L. Carew, pers. comm. 1985).

As noted above, the apices of conulariids in other radial clusters are not preserved, and a basal apatitic sheet has never previously been recorded. This sheet does not conform to any known non-conulariid fossil, nor does it resemble inorganic structures such as desiccation/ synacresis cracks or cement-filled fractures. Instead, the sheet is most similar to the smooth, frequently crumpled test material forming conulariid schotts, which are repair structures covering the apical ends of individuals that were severed in life (Werner 1967; Van Iten 1987, $1991 \mathrm{c})$. The apparent continuity of test material between the sheet-like feature and at least two of the three conulariids in USNM 50145, coupled with similarities in their color and texture, suggest that the sheet represents apatitic conulariid test material.

\section{Scyphozoan polyp colonies}

Advocates of a scyphozoan affinity for conulariids have noted detailed similarities between conulariids and members of the thecate scyphozoan order Coronatida (e.g. Werner 1966, 1967;
Bischoff 1978, 1989; Van Iten 1991b, 1992a, b). Polyps of this order are sheathed in a non-mineralized, multilamellar periderm, and in many species the polyp is colonial. Polyp colonies of some coronatids arise from a thin, sheet-like mass, called the scyphorhiza, of entwined budding stolons (e.g. Werner 1970, 1979). The scyphorhiza is covered by a sheet of periderm that is confluent with the basal ends of the peridermal tubules of the polyps. This is similar to the apical ends and associated sheet-like structure of conulariids in USNM 50145.

Kozłowski's (1968) observations suggest that conulariids normally tapered to a minute ( $<1 \mathrm{~mm}$ wide), almost pointed apex. As indicated above, however, at least two of the conulariids in USNM 50145 appear to merge into the basal sheet at a level well above the point where one might expect the apex to occur. A possible explanation of this apparent anomaly is suggested by reference to a series of experiments conducted by Werner (1970) to investigate the regeneration capabilities of the colonial coronatid, Stephanoscyphus racemosus Komai. Werner severed individual polyps of this species near the apex and observed that they responded by forming a 'flat, irregularly shaped disc of cell material [the basal regeneration body] which attaches to the substratum, and which then transforms into a true attaching disc [scyphorhiza]. This basic dise becomes enveloped with a membrane of periderm and produces... new flat [budding] stolons from which new polyps will be produced (Werner 1970:15-16). The periderm of the new polyps merges into the 'basic disc', resulting in an erect, nearly radial cluster, and, importantly, new polyps have relatively broad diameters at their point of emergence from the 'basic disc' (Werner 1970: fig. 10).

We propose that USNM 50145 most closely resembles a coronatid polyp colony produced from a regenerative ancestor. The presence of a basal sheet of apatitic test material and the apparent continuity between it and the conulariid tests excludes known settlement phenomena as an explanation. The relatively wide diameter of two of the conulariids near the sheet suggests that USNM 50145 and Werner's regenerated coronatid colonies were produced by similar processes, and that the apatitic sheet in USNM 50145 represents a structure either analogous or homologous to the coronatid basal regeneration body. 


\section{Implications for conulariid affinities}

Recent proposals for the affinities of conulariids have placed them in their own phylum (e.g. Feldmann \& Babcock 1986; Babcock \& Feldmann 1986a, b, c; Babcock 1991; Yochelson 1991), as relatives of chordates (Steul 1984), or as relatives of scyphozoan cnidarians (e.g. Werner 1966, 1967; Bischoff 1978. 1989; Van Iten 1991b, 1992a, b). In comparing USNM 50145 with these alternative models for the interpretation of conulariids, the presence of an apatitic basal sheet seems consistent only with the hypothesis of a scyphozoan affinity for conulariids: no similar structure is known from chordates or other non-cnidarian taxa.

Secondly, the inference that conulariids possessed the capacity for clonal budding and/or regeneration provides a further point of similarity with cnidarians, and would serve to reject hypotheses of a chordate affinity (Steul 1984), though some protochordates (e.g. urochordates) do produce clonal colonies (Barnes 1987).

Finally, although USNM 50145 was collected from Pennsylvanian strata in North America, well-preserved conulariids occur in similar strata in Europe (e.g. shales in the Coal Measures of Great Britain; Slater 1907). In view of the potential significance of USNM 50148 to discussions of conulariid affinities, it is important that the search for similar but better preserved clusters be extended to areas outside North America.

Acknowledgments. - We thank F. J. Collier for permission to borrow USNM 50145, T. Van Iten for printing the photographs, and R. M. G. Macleod for digesting a draft of this paper. Permission to borrow or examine other conulariid clusters was granted by T. Bolton, F. J. Collier. D. C. Fisher, J. Golden, J. T. Hannibal, R. P. S. Jeffries, E. Landing and A. B. Smith. This study was supported by funding from the Department of Geological Sciences and the Horace H. Rackham School of Graduate Studies at the University of Michigan both to HVI and RSC, and from Sigma Xi and R. J. and H. B. Van Iten to HVI.

\section{References}

Babcock, L. E. 1991: The engima of conulariid affinities. In Simonetta, A. M. \& Conway Morris, S. (eds.): The Early Evolution of Metazoa and the Significance of Problematic Taxa, 133-143. Cambridge University Press, Cambridge.

Babcock, L. E. \& Feldmann, R. M. 1986a: Devonian and Mississippian conulariids of North America. Part A. General description and Conularia. Annals of the Carnegie Museum 55, $349-410$.

Babcock, L. E. \& Feldmann. R. M. 1986b: Devonian and Mississippian conulariids of North America. Part B. Para- conularia, Reticulaconularia, n. gen. and organisms rejected from Conulariida. Amals of the Carnegie Musewm 55, $411-$ 479

Babcock, L. E. \& Feldmann, R. M. 1986c: The phylum Conulariida. In Hoffman, A. \& Nitecki, M. H. (eds.): Problematic Fossil Taxa, 135-147. Oxford University Press, Oxford.

Babcock, L. E., Feldmann, R. M., Wilson, M. T. \& M Suárez-Riglos. 1987: Devonian conulariids of Bolivia. $\mathrm{Na}$ tional Geographic Research 3, 210-231.

Barnes. R. D. 1987: Invertebrate Zoology, fifth edition. $893 \mathrm{pp}$. Saunders College Publishing, Philadelphia.

Bischoff. G. C. O. 1978: Internal structures of conulariid tests and their functional significance, with special reference to Circoconulariina n. suborder (Cnidaria, Scyphozoa). Senckenbergiana Lethaea 59, 275-327.

Bischof, G. C. O. 1989: Byroniida new order from early Palaeozoic strata of eastern Australia (Cnidaria, thecate scyphopolyps). Senckenbergiana Lethaea 69, 467-521.

Feldmann, R. M. \& Babcock, L. E. 1986: Exceptionally preserved conulariids from Ohio - reinterpretation of their anatomy, National Geographic Research 2, 464-472.

Finks, R. M. 1955: Conularia in a sponge from the West Texas Permian. Journal of Paleonology 29,831-836.

Finks, R. M. 1960: Late Paleozoic sponge faunas of the Texas region. The siliceous sponges. Bulletin of the American $\mathrm{Mu}$ seum of Natural History 120,7-160.

Harland, T. L. \& Pickerill, R. K. 1987: Epizoic Schizocrania sp. from the Ordovician Trenton Group of Quebec, with comments on mode of life of conulariids. Journal of Paleontology. $61,844-849$

Kozłowski, R. 1968: Nouvelles observations sur les conulaires. Acta Palaeontologica Polonica 13,497-53!

Rooke, H. G. \& Carew, J. L. 1983: New light on a poorly understood fossil group. Geological Society of America, $A b$ stracts with Programs 15(2), 53.

Ruedemann, R. H. 1925: The Utica and Lorraine Formations of New York. Part 2. Systematic Paleontology. No. i. Plants, Sponges, Corals, Graptolites, Crinoids, Worms, Bryozoans, Brachiopods. New York State Museum Bulletin 262, 171 pp.

Sinclair. G. W. 1940: A discussion of the genus Metaconularia with descriptions of new species. Royal Society of Canada. Section IV, Transactions, Series 3, 34, $101-121$

[Sinclair, G. W. 1948: The biology of the Conularida. $428 \mathrm{pp}$ Unpublished PhD. dissertation, McGill University, Montréal.]

Slater, I. L. 1907: A monograph of the British Conulariae. Palaeontographical Society, London 61, 1-40

Steul, H. 1984: Die systematische Stellung der Conularien. Giessener Geologische Schriften $37,117 \mathrm{pp}$.

Termier. H. \& Termier, G. 1949: Position systématique el biologie des Conulaires. Revue Scientifique 86, 711-722.

Termier, H. \& Termier, G. 1953: Les conularides. In Piveteau, J. (ed.): Traité de Paléontologie. Tome III. Onychophores, Arthropodes, Echinodermes, Stomocordes, 1006-1013. Masson \& Cie., Paris.

Van Iten, H. 1987: Mode of life of the Conulariida and its implications for conulariid affinities. Geological Society of America, Abstracts with Programs 19(7), 876.

Van Iten, H. 1991a: Repositories of and additional comments on sponge specimens containing molds of Paraconularia. Journal of Paleontology 65, 333-335.

Van Iten, H. 199lb: Evolutionary affinities of conulariids. In Simonetta, A. M. \& Conway Morris, S. (eds.): The Early Evolution of Metazoa and the Significance of Problematic Taxa. 145-155. Cambridge University Press, Cambridge. 
Van Iten, H. 1991c. Anatomy, patterns of occurrence, and nature of the conulariid schott. Palaeontology 34, 939954.

Van Iten, H. 1992a. Morphology and phylogenetic significance of the corners and midlines of the conulariid test. Palaeontology 35. $335-358$.

Van Iten. H. 1992b. Microstructure and growth of the conulariid test: implications for conulariid affinities. Palaeontology 35, $359-372$.

Werner, B. 1966: Stephanoscyphus (Scyphozoa, Coronatae) und seine direkte Abstammung von den fossilen Conulata. Helgoländer Wissenschaftliche Meeresuntersuchungen 13,317347.

Werner. B. 1967: Stephanoscyphus Allman (Scyphozoa, Corona- tae), ein rezenter Vertreter der Conulata? Paläontologische Zeitschrift 41, 137-153.

Werner, B. 1970: Contribution to the evolution in the genus Stephanoscyphus (Scyphozoa Coronatae) and ecology and regeneration qualities of Stephanoscyphus racemosus Komai. Publications of the Seto Marine Biological Laboratory 18, $1-20$.

Werner, B. 1979: Coloniality in the Scyphozoa: Cnidaria. In Larwood, G. \& Rosen, B. R. (eds.): Biology and Systematics of Colonial Organisms, 81-103. Academic Press, London.

Yochelson, E. L. 1991: Problematica-incertae sedis. In Simonetta, A. M. \& Conway Morris, S. (eds.): The Early Evolution of Metazoa and the Significance of Problematic Taxa, 287-296. Cambridge University Press, Cambridge.

\title{
Comments on downward growth within Cylindrophyllia (=Peponocyathus) orientalis, a solitary coral from the Pleistocene of Japan
}

\author{
GABRIEL A. GILL
}

In 1983, Mori and Minoura discussed in Lethaia the occurrence of identical numbers of septa on both the upper and lower sides of the minute discoidal to cylindrical free solitary coral Cylindrophyllia orientalis (Yabe \& Eguchi, 1932). The authors were inclined to believe that (p. 189): 'In the present species, almost all the specimens possess the same number of septa during the ontogeny. In other words, all the septa in each individual were developed almost simultaneously in a very short time interval at its earliest stage of skeletal development, and were kept during ontogeny. It is therefore highly probable that the total number in each corallum has been genetically induced, having already been determined at the larval stage before settlement on the bottom prior to skeletal formation.' Some eight hundred specimens, all from the Pleistocene of Kagoshima Prefecture, had been examined by the authors.

Studies of fossil and Recent skeletons of free mobile corals (Chomatoseris, Genabacia, Combophyllum, Cycloseris and others - Gill 1967, 1972, 1977: Gill \& Coates 1977: Gill et al. 1978; Gill \& Semenoff Tian-Chansky 1971), where downward growth is simultaneous with proximal and lateral development, made me think that in one way or another it might be also the case within the skeleton of Cylindrophyllia orientalis. As a rule, centrifugal growth takes place only when the skeleton is totally invested by the living tissue. The overall presence of the secretory epithelium produces simultaneously by its continuity the same number of septal elements on all sides, without leaving an epitheca. Therefore, within a mature down-growing coral the initial older part of the skeleton should not be looked for at the outer basal side but rather inside the skeleton, along the growth axis, below the coral's geometric center (Gill 1977: pl. 10, fig. 1; Gill \& Coates 1977: fig. 6A, B). Professor Kei Mori was kind enough to send me some specimens to check such a possibility.

In a recent abstract and poster at the 6th International Symposium on Fossil Cnidaria. Stolarski (1991) described a reproductive transverse division in Peponocyathus duncani (Reuss) from the Tertiary of Poland. The author reported the presence of numerous morphologically similar Peponocyathus anthocauli and anthocyathi in Miocene deposits at the Holy Cross mountains. Mori and Minoura have not taken into account such an ontogeny which had been partially hinted at by Denant (1906) and clearly introduced by Squires (1964) within Kionotrochus, a genus synonomized with Peponocyathus by various authors. This mode of reproduction was later supported by Zibrowius (1980) and Brook (1982). Cairns too enumerated $P$. folliculus (1988:644) among corals that reproduce by transverse asexual division yet shortly after he resolutely excluded this character from the generic diagnosis of Peponocyathus (Cairns 1989:29 - 'transverse division lacking'). He considers Cylindrophyllia orientalis synonymous with Peponocyathus folliculus, to which he gives priority (1989:30), while Kionotrochus would be a distinct form, endemic to New Zealand (1989:29, 30). Brook's $(1982: 169,170)$ comments on ontogeny within Recent Kionotrochus suteri from New Zealand mention downwards growth of costae, which may be partially resorbed and secondarily costate. He also notes a clear onset of transverse fission.

None of the studies carried out hitherto have been supported by thin section observation.

Without intending to devote further study to the intriguing ontogeny of Cylindrophyllia = (Peponocyathus) I wish to communicate here illustrations of a longitudinal section that $I$ processed in one of the specimens from Japan. Downward growth, though of limited extension (c. $10 \%$ of the total height), is clearly observable. This basal development indicates that at least during the period of its formation, growth was simultaneous all around the skeleton, a fact which by itself assures the appearance of an equal number of septa or costae all around and their simultaneous multiplication. 